he uses-a revealing admission in a book about the science of control and communication! But, once this barrier is overcome, the book repays careful study; it can add considerably to an understanding of some of the problems discussed, for instance, by Dr. Carthy in his book. In fact, Dr. George stimulates thought about the various principles which may be involved in a great many biological processes that are usually taken for granted.

The authors of these volumes have evidently had few limitations imposed upon them by the publishers-as should be the situation when they are as expert in their subjects as these. The books are of various lengths, and exhibit a variety of treatment; but each one contains a longer or shorter list of references for broader or more detailed reading. In paperback or hard covers, the series is very well produced, with illustrations that are generally good although differing a little in quality from volume to volume. If subsequent volumes in the series maintain the standards set by the first six, then University Reviews in Biology will become a valuable, almost indispensable, part of the libraries of university students and teachers alike.

K. C. Higunam

\section{CONTROL OF GLYCOGEN METABOLISM}

\section{Control of Glycogen Metabolism}

Edited by Dr. W. J. Whelan and Margaret P. Cameron. (A Ciba Foundation Symposium.) Pp. xiv + 434. (London: J. and A. Churchill, Ltd., 1964.) $60 s$.

\section{$\mathrm{T}$}

HE latest addition to the invaluable series of Ciba Foundation symposia generously covers the field described in its title. The range of the numerous papers presented permits discussion of the synthesis and catabolism of glycogen, and its control by enzymatic and hormonal influences, together with an important section on the glycogen storage diseases. The editors, and in particular Prof. W. J. Whelan, are to be congratulated on the skilful way in which the complex assembly of papers and discussions on papers has been welded into the unified text of a book of great importance.

The book begins with a most stimulating article by French on the structurc of glycogen evolving a concept of steric limitation in size of the Meyer model. This, together with the paper by Orrell, Bueding and Reissig, which offers a careful evaluation of the methods of preparing undegraded glycogen, serves to visualize the molecule and to restate the problems still unsolved in the structure of the particle.

A large section of the symposium is given up to papers on the present-day viewpoints of such enzymes as phosphorylases, branching and debranching enzymes. Here particularly the papers by E. G. Krebs et al. on the nature of the phenomenon leading to the appearance of catalytic activity in the phosphorylase molecule and its control are of great interest. This work receives interesting crossillumination from the papers of Cori and Brown, who individually discuss the contribution of phosphorylase to the determination of the structure of glycogen and its role in the regulation of glycolysis in skeletal muscle. The further paper by Sutherland on the location of adenyl cyclase and adenosine $3^{\prime}, 5^{\prime}$-phosphate deserves close attention, as do the discussions which follow each of these accounts. Here perhaps is the most stimulating part of this book and clearly by the co-operative picture that emerges on present-day concepts of phosphorylase action more than justifies the assembling of so many talents together in a symposium.

Though so much work on one cnzyme might suggest the neglect of others, the great variety of articles by the groups of Whelan, Larner, Brown and Hers would firmly refute such an imputation. Part of the problem would appear to be that there are more enzymes known than there are physiological functions for them to fulfil. However, much information is now available on the mechanism of debranching of glycogen structure. One wish that I would make is that some suitable enzyme nomenclature for these catabolic reactions should emerge in the near future. In addition, the papers by Larner on the branching enzyme and Hers on the mechanism of action of amyloglucosidase demonstrate the subtlety of experimental approach needed in elucidating the action pathways. Rosenfeld's paper reports a new mammalian enzyme$\gamma$-amylase-and reports on $\gamma$-dextrins. The paper by Prof. Whelan et al. lies at the heart of what may be called the Cori-Whelan controversy as to the structuro of the branched chains in glycogen; there can be little doubt that Prof. Whelan is correct in his deductions.

The paper by Leloir on the role of uridine diphosphate glucose in the synthesis of glycogen is a model of lucid presentation and relevance, as anyone who heard his opening lecturo in New York in 1964 will agree. One aspect which he mentioned there and which provoked much thought was his interpretation of the phosphorylase activation mechanism. Following Macfarlane's explanation of blood clotting as a multiplying system serving as a biochemical amplifier (Nature, 202, 498; 1964), Leloir postulated that a similar cascade of proenzyme-enzyme transformations might serve just such a purpose in the interconversions centred around the phosphorylase molecule.

Later articles in the symposium deal with the difficult territory of hormonal interaction on physiological systems, and the interpretation of these and other effects in tcrms of control over the enzyme sequences involved. Noteworthy in this class, of course, are the papers by Morgan and by Larner. The former is a closely argued account of the allosteric properties of phosphorylase $b$ studied in the perfused rat heart where glycogenolysis had been stimulated by glucagon and anoxia. Larner's paper deals with the role of insulin in the control of glycogen synthetase. Together with these papers, the account of Bueding on the offects of adrenæline on intestinal smooth muscle, and the speculations of Randle on some indirect actions of adrenaline on glycogen metabolism, give this section of the symposium a pleasing sense of integrity.

The final section of the symposium deals with glycogen storago disoases. This is well presented; many of the previous contributors who dcalt with the biochemical implications return to deal with the clinical quandaries of the subject. In particular Manners, whose excellent review of glycogen metabolism appeared in 1963, discusses type I glycogenosis, and is followed by other workers discussing the known diseases. Stimulating possibilities exist in the finding by Spencer-Peet of cases of glycogen synthetase deficiency.

The symposium closes with a discussion and a recapitulation of the main thoroughfares of glycogen metabolism.

C. F. Phelps

\section{RECENT ADVANCES IN PSYCHOPHARMACOLOGY}

Animal Behaviour and Drug Action

Edited by Dr. Hannah Steinborg, A. V. S. de Reuck and Julie Knight. (Ciba Foundation Symposium jointly with the Co-ordinating Committee for Symposia on Drug Action.) Pp. xiv +491 . (London: J. and A. Churchill, Ltd., 1964.) 67s. 6d. net.

THE major part of Animal Behaviour and Drug Action is a compilation of papers and discussions presented at an international symposium, the aim of which was to examino tho role of animal behaviour in investigations of drugs affecting the contral norvous system. The book constitutes a welcome addition especially to tho booksholf 